\title{
Teaching Effectiveness and Morale of Criminology Faculty of Laguna State Polytechnic University, Philippines
}

\author{
Kristelle Ann R. Torres", Joy G. Laduyo, Christy Liane R. Niem \\ College of Criminal Justice Education, Laguna State Polytechnic University-Los Baños Campus, Philippines
}

Received January 6, 2020 ; Revised June 11, 2020; Accepted June 16, 2020

Copyright $\odot 2020$ by authors, all rights reserved. Authors agree that this article remains permanently open access under the terms of the Creative Commons Attribution License 4.0 International License

\begin{abstract}
Improving the quality of the faculty supposed to be a main concern in improving the quality of education. Therefore, this study was conducted to assess the teaching effectiveness and morale of criminology faculty of Laguna State Polytechnic University, Philippines using descriptive-correlational method. The study employed the complete enumeration of the faculty of Criminology of the mentioned University for the First Semester Academic Year 2018-2019 which was thirty-four (34). Descriptive statistics such as frequency and percentage, weighted mean, independent t-test, one-way analysis of variance (ANOVA), and pearson correlation were employed using Statistical Package for the Social Sciences (SPSS) data base software. Results revealed that no significant relationship was found between the profiles and morale of criminology faculty. Oppositely, there was significant relationship between the civil status and status of appointment-profile and teaching effectiveness. This signifies that the aforesaid profile-variables are important in rating the teaching effectiveness of the faculty. This information may be useful in the faculty training program and serves as a guide in higher education classrooms, particularly in criminology education. Although no significant influence was found between teaching effectiveness and morale, it still provides an important perspective as to what is necessary to further develop and foster a working environment that will aid the faculty to be the best possible resource of the University. With this, faculty of Criminology will perform responsibilities with initiatives to continually improve the quality of education delivered to their clientele, particularly students, and contribute to the realization of the University's vision, mission and quality policy.
\end{abstract}

Keywords Criminology Faculty, Morale, Teaching Effectiveness

\section{Introduction}

A faculty plays a vital role in a university's success and good reputation, both with the students and academia [1]. To be employed as a faculty in a university requires the faculty to be proficient. It is a way to promote students' learning by assuring not only the quality of faculty in their own area of discipline but also seeing to it that the students meet faculty who are professionals. There are four components of effective educator according to personal qualities, professional qualities, social qualities, and instructional skills. The researchers are aware that all these qualities are to be measured for major decisions about the future. These decisions have an impact on the quality of the professional life. Then, teaching performance may be employed through various sources of evidences like student ratings, peer ratings, administrator ratings, and learning outcome measures [2,3].

The faculty of the College of Criminal Justice Education must perform what is expected of them with utmost dedication towards attaining its goal, which is to deliver quality education to be more globally competitive. The College is expected to continually improve its level of performance and must be able to produce more competent student learning and a more productive culture. As teachers, they should advance their levels of performance to create deeper levels of learning and improved levels of skill development. Being aware of the function and responsibility could lead to various implications associated with improving the quality of education as an agent of change.

Thus, quality of education can be enhanced through the motivation of faculty, the faculty's feelings toward the 
University, and atmosphere created. The faculty is responsible for teaching in the classroom and dealing with the students throughout the school days. Rauf et al. [4] cited that if the faculty feels positive to the responsibilities at school, the positive effect will be shown to the students and schools, or vice versa. Consequently, teachers who have satisfaction and high spirit will act actively to engage in the process of teaching and learning. Shalem \& Hoadley [5] mentioned that students' achievement in examinations is often associated with teachers' low morale. Therefore, faculty morale contributes to their performance and to the students' academic achievement. They perform a significant role in the educational institution's success and its status with the students and academics [6], thus, improving the quality of education.

The compelling reason for conducting this study has been based on the usual claim of the faculty. It has been said that educational bureaucracy is interfered, resulting in inadequate facilities and lack of administrative support. Since teaching takes place in a specific physical location, the quality of that location can affect the ability of the faculty to teach and their morale. In terms of administrative support, although the administrator might be able to approach, they still feel like the concerns are not being addressed. This also influences the same as it could minimize the effectiveness and overall success of the faculty. Serious deficiencies have been well observed despite of their importance.

As a member of the Organization, the researchers consider it as their responsibility to explore possibilities of helping the University solve the problems and issues, particularly in the field of criminology education. As an initial step, the researchers sought to find out the causes of the problems relevant to the performance and morale of the teachers of the University.

With this, the main goal of this study was to assess the teaching effectiveness and morale of Criminology faculty of LSPU. Specifically, it sought to attain the following objectives:

1. Determine the profile of the respondents in terms of age; gender; civil status; religion; educational attainment; length of service in the University; and status of appointment.

2. Know the level of morale of a long relationship towards superiors and administrators; relationship towards fellow faculty; attitudes towards school works; professionalism; and public relations

3. Identify the level of teaching effectiveness in terms of course/subject matter organization; mastery of the subject matter; teaching approach; command of language; and regency and relevancy of concepts/materials

4. Establish if there is a significant relationship between the profile and morale; profile and teaching effectiveness; and teaching effectiveness and morale.

The results from this study may offer the recommendations and influences to enhance the quality of teaching in criminology education program of the University. This study may enable criminology faculty to learn insight on how to do a better job teaching their classes in order to enhance the achievement of their educational goals and objectives. Higher educational administrators, planners, and decision-makers may find the information generated helpful in gaining better insights and how to improve them for greater effectiveness of the teaching-learning process. The recommendations that will be offered by the study may likewise shed light on promoting quality education.

\section{Materials and Methods}

In order to achieve the research objectives, the researchers used descriptive-correlational research design for the study. The study was conducted at Laguna State Polytechnic University otherwise known as "LSPU" in which the researchers are currently employed as regular faculty of the College of Criminal Justice Education. The University includes four satellite campuses, namely: Sta. Cruz Campus, which is the main campus located at Brgy. Bubukal, Sta. Cruz, Laguna; while three extension campuses include the Los Baños Campus, San Pablo City Campus, and Siniloan (Host) Campus located at Brgy. Malinta, Los Baños, Laguna; Brgy. Del Remedio, San Pablo City, Laguna; and L. De Leon St., Siniloan, Laguna, respectively. The total population of criminology faculty during the first semester of academic year 2018-2019 was thirty-four (34). The researchers used the total of 34 faculties taken from the four campuses of the LSPU system. They represent 100 percent of the teaching force, both full time and part time. Hence, complete enumeration sampling technique was used. The respondents consisted of five (5) criminology faculty from Los Baños Campus, nine (9) criminology faculty from San Pablo Campus, ten (10) criminology faculty from Sinoloan Campus, and ten (10) criminology faculty from Sta. Cruz Campus.

The study utilized the survey questionnaire which consisted of two parts. The first part was used to determine the profile of the respondents. The second part of the survey questionnaire purportedly determined the level of morale of the faculty. This was adapted from the study of Bayona [7]. Before the questionnaire was adapted, the researcher asked the author's permission to use and print the questionnaire under agreed conditions indicated by the latter's signature on the request.

However, in determining the teaching performance of the respondents, the First Semester Academic Year 2018-2019 teaching performance results were utilized in the study. The teaching performance was rated independently by the students enrolled on the mentioned period. The data were respectfully requested to the Office of the Dean and Associate Deans of the CCJE. Descriptive statistics such as frequency and percentage, weighted mean, 
independent t-test, one-way analysis of variance (ANOVA), and pearson correlation were employed using Statistical Package for the Social Sciences (SPSS) data base software.

\section{Results and Discussion}

The table below discloses that $15(44.1 \%)$ of the respondents are 30 years old and below. Out of 34 respondents, $19(55.9 \%)$ of them are male while $15(44.1 \%)$ are female. Majority of the respondents are married (19 or $55.9 \%$ ) and Catholic (23 or $67.7 \%$ ). The educational attainment of the majority of the respondents is master degree $(47.1 \%)$, and they have been serving $1-4$ years in the Institution (58.8\%). Seen in the same table that most of the respondents $(50 \%)$ are part-time faculty followed then by $12(35.3 \%)$ who are permanent faculty.

Table 1. Distribution of the Respondents

\begin{tabular}{|c|c|c|}
\hline Profile of Respondents & Frequency & Percentage \\
\hline \multicolumn{3}{|l|}{ Age } \\
\hline 30 years old and below & 15 & 44.1 \\
\hline $31-40$ years old & 8 & 23.5 \\
\hline 41 years old and above & 11 & 32.4 \\
\hline \multicolumn{3}{|l|}{ Gender } \\
\hline Male & 19 & 55.9 \\
\hline Female & 15 & 44.1 \\
\hline \multicolumn{3}{|l|}{ Civil Status } \\
\hline Single & 15 & 44.1 \\
\hline Married & 19 & 55.9 \\
\hline \multicolumn{3}{|l|}{ Religion } \\
\hline Catholic & 23 & 67.6 \\
\hline Non-Catholic & 11 & 32.4 \\
\hline \multicolumn{3}{|l|}{ Educational Attainment } \\
\hline Bachelor's Degree & 12 & 35.3 \\
\hline Master's Degree & 16 & 47.1 \\
\hline $\mathrm{PhD} /$ Bachelor of Law & 6 & 17.6 \\
\hline \multicolumn{3}{|l|}{ Length of Service in LSPU } \\
\hline $1-4$ years & 20 & 58.8 \\
\hline $5-8$ years & 7 & 20.6 \\
\hline $9-12$ years & 7 & 20.6 \\
\hline \multicolumn{3}{|l|}{ Status of Appointment } \\
\hline Permanent & 12 & 35.3 \\
\hline Temporary & 5 & 14.7 \\
\hline Part-time & 17 & 50 \\
\hline
\end{tabular}

Table 2 shows that the level of morale of Criminology Faculty of LSPU in terms of relationship towards supervisors and administrators was high with a mean of 4.38. This implies that the administration and leaders influence the teachers. This means that the Criminology faculty feels the support and encouragement from the management. This finding is opposed to the results of the study of Bivona [8], in which only 10 percent of the teachers strongly agreed, and 40 percent somewhat agreed that the school administration supports and encourages the staff. While 35 percent somewhat disagreed, and 15 percent strongly disagreed on such statement. The result implies that some teachers have a good rapport with the administration; hence, they feel that they are being supported and encouraged. Those who disagreed are not getting the same feeling from the administration, as revealed by the interview conducted. According to them, they feel that they receive very little support from the administration. The morale of teachers can be improved and fostered by the school leaders [9]. Whitaker, Whitaker \& Lumpa [10] found that morale could be improved by acknowledging and strengthening the positive things that are done by teachers in their daily work at the school. With this, it is concluded that morale can lead to the organization's success or otherwise.

Table 2. Level of Morale of the Criminology Faculty of LSPU

\begin{tabular}{|l|c|c|}
\hline \multicolumn{1}{|c|}{ Indicators of Morale } & Mean & $\begin{array}{c}\text { Descriptive } \\
\text { Interpretation }\end{array}$ \\
\hline $\begin{array}{l}\text { 1. Relationship towards } \\
\text { superiors and administrators }\end{array}$ & 4.38 & High Morale \\
\hline $\begin{array}{l}\text { 2. Relationship towards } \\
\text { fellow faculty }\end{array}$ & 4.47 & High Morale \\
\hline $\begin{array}{l}\text { 3. Attitudes towards school } \\
\text { works }\end{array}$ & 4.53 & High Morale \\
\hline 4. Professionalism & 4.54 & High Morale \\
\hline 5. Public relations & 4.11 & $\begin{array}{c}\text { Above Average } \\
\text { Morale }\end{array}$ \\
\hline
\end{tabular}

Legend: High Morale=4.21-5.00; Above Average Morale=3.41-4.20; Below Average Morale=1.81-2.60; Low Morale=1.00-1.80

In terms of relationship towards fellow faculty, the level of morale of the respondents was high with a mean of 4.47. The result denotes that the respondents are communicating, collaborating, or sharing their expertise with their colleagues. This result is consistent with Dubey [11] who found a highest teachers' morale score of the factor rapport among the teachers (4.03). It is likewise, stated that no employee irrespective of its profession would be confident and content if the relationship with the colleagues is not harmonious. The finding is also same with Goldstein [12] as she mentioned that there was significant positive influence between collaboration and a teacher's morale. This influences how a teacher performs the job, meets and greats fellow educators, and interacts with students. Moreover, Hasan [13] concluded that co-workers' motivational efforts have a huge impact on employee morale as co-workers are the ones who support and guide them at the work place and are the sources of positive spirit, which leads towards the accomplishment of objectives.

Also, the level of morale in terms of attitude towards school works was high with a mean of 4.53 . It can be 
deduced that the respondents, as faculty, accept teaching as their profession. They consider themselves as guides, coaches and leaders in the process of teaching and learning. Brown \& Richard [14] cited that teachers with positive attitude do not show mistakes of students, rather they work to improve their talents and enhance their skills and strengths. The finding is same on the preliminary analysis of Harthy, Jamaluddin \& Abedalaziz [15] who found that the teachers mostly have positive attitudes towards teaching. Usop et. al. [16] research was moderately analogous to the above finding in which the teachers were somewhat satisfied on the work itself. The highest mean was interpreted as very satisfied which referred to "Diligent towards work". The author implied that teacher-respondents were very satisfied with their work. However, "work with pride" got the lowest mean which was interpreted as somewhat satisfied. This implies that working with pride is one way to satisfy the teachers with their job. Conversely, the study did not conform to the study of Choudhary as cited by Chella Pandian [17], which showed that most of the executives of the lower level find that their jobs are not in line with their attitudes. Such executives, being in direct contact with the non-supervisory staff, can pass on their feelings and attitudes to a large number of employees in the organization. Overall morale in an organization, therefore, can continue to be poor.

In addition, the level of morale in terms of professionalism was high with a mean of 4.54 . It can be observed from the finding that the respondents recognize the need to demonstrate professionalism in all aspects of their career. They really show their professional demeanor as they take their responsibilities seriously. This finding conforms to study made by Nicodemus [18] which found that the teacher has high morale when it comes to themselves and their profession. Teachers view their profession as the noblest one and the most fulfilling. In addition, teachers are aware of their rights, responsibilities, and accountabilities, which gives them confidence in performing their assigned tasks because they know what is expected of them and how to perform it. The findings of Tanang \& Abu [19] indicate that the teachers of South Sulawesi, Indonesia, practice the characteristics of professional as teachers and educators focused on their behavior and attitude in performing their duties and responsibilities. The professional practices are shown in improving pedagogic skills in teaching and seeking professional development activities. They perform good commitment and responsibility toward the students and profession.

However, the level of morale of in terms of public relations was above average with a mean of 4.11. Conversely, the finding did not corroborate to the findings of Bayona [7] which found that the faculty members have the highest faculty morale in terms of public relations. The result could lead to necessity for the enhancement of respondents' morale on public relations. Administrators may recognize the importance of building a strong school community and the relationship between sense of community and staff morale. There will be many benefits to the entire school community if the administrator spends time and energy to develop a team of teachers that work together regularly [20].

Table 3 shows the level of teaching effectiveness of the respondents as provided by the deans of the College of Criminal Justice Education of the four campuses of LSPU. All the indicators received weighted means ranging from 4.53 to 4.59 , with composite mean of 4.56 interpreted as very good.

It can be inferred from the findings that the criminology faculty of LSPU possess the effective professional characteristics as expected to a professional educator. The ratings of Very Good of all the indicators give the researcher the idea that there is still room for improvement to make it "Outstanding" rating in the future.

Table 3. Level of Teaching Effectiveness of Criminology Faculty of Laguna State Polytechnic University

\begin{tabular}{|l|c|c|}
\hline \multicolumn{1}{|c|}{$\begin{array}{c}\text { Indicators of Teaching } \\
\text { Effectiveness }\end{array}$} & Mean & $\begin{array}{c}\text { Descriptive } \\
\text { Interpretation }\end{array}$ \\
\hline $\begin{array}{l}\text { 1. Course/subject matter } \\
\text { organization }\end{array}$ & 4.54 & Very Good \\
\hline 2. Mastery of the subject matter & 4.58 & Very Good \\
\hline 3. Teaching approach & 4.53 & Very Good \\
\hline 4. Command of language & 4.59 & Very Good \\
\hline $\begin{array}{l}\text { 5. Regency and relevancy of } \\
\text { concepts/materials }\end{array}$ & 4.56 & Very Good \\
\hline
\end{tabular}

The findings were supported by the data results from the study of Hidalgo, Lamberte \& Manalo [21] when the associate dean, peers, and students assessed the performance of criminology instructors as "very satisfactory" along with instructions. In contrast, the criminology instructor themselves assessed their performance as outstanding. The authors cited that although the associate dean, peers, and students assessed the criminology instructors as very satisfactory, the criminology instructors for them did a great job in terms of instruction. For criminology instructors, they believed that they were highly effective since they were able to deliver the instructions successfully and had an understanding of how to best deliver the lesson for the subject.

Same result was found in the research made by Verceles \& Rivera [22] in which the over-all mean distribution of faculty teaching performance of the College of Education showed a "very satisfactory" rating. It then implied that the $\mathrm{CE}$ faculty was performing very well. It was connoted that the faculty members were committed and dedicated to their work.

Agsalud [23] also found that the level of teaching effectiveness of faculty members of Pangasinan State University was "very Satisfactory" in terms of commitment, knowledge of subject matter, teaching for 
independent learning, and management of learning as rated by the students.

Sali-ot [24] study also agreed with the above finding that teachers were highly competent in the five measures of the teaching skills in terms of planning, teaching resources, teaching strategies and techniques, communication with learners, learner reinforcement-involvement, and professional standards.

However, the findings were opposed to the research of Umali [25] when the teachers' performance and the related factors of different colleges at Laguna State Polytechnic University San Pablo City Campus Academic Year 2010-2011 were determined. "Outstanding" performance was found according to commitment, knowledge of the subject, teaching strategies, and management. The author connoted that the teachers were committed to their profession, knew the subject in which they taught, enabled the learners to be existential in knowledge, and served as facilitators and provided materials.

Table 4. Test of the Significant Relationship between the Profile and Morale of Criminology Faculty of LSPU

\begin{tabular}{|c|c|c|}
\hline Profile-Variables & t-value & p-value \\
\hline Gender & 0.949 & 0.350 \\
\hline Civil Status & 0.114 & 0.910 \\
\hline \multirow[t]{2}{*}{ Religion } & 1.034 & 0.309 \\
\hline & f-value & p-value \\
\hline Age & 0.862 & 0.432 \\
\hline Educational attainment & 3.037 & .062 \\
\hline Length of service in LSPU & 1.476 & 0.244 \\
\hline Status of appointment & 2.745 & 0.080 \\
\hline
\end{tabular}

It is clearly exhibited in the above table that the profiles and morale of criminology faculty found to have no significant relationship. Therefore, it can be said that morale was not associated with demographic characteristics of the respondents. The faculty's profile variables do or do not to a small extent, influence their morale. The finding provided a great signal that faculty from different demographic characteristics maintains favorable level of morale; hence it will contribute positively to the University.

Table 5. Test of the Significant Relationship between the Profile and Teaching Effectiveness of Criminology Faculty of LSPU

\begin{tabular}{|c|c|c|}
\hline Profile-Variables & t-value & p-value \\
\hline Gender & .225 & .823 \\
\hline Civil Status & 2.312 & $.027^{* * *}$ \\
\hline Religion & .011 & .991 \\
\hline & f-value & p-value \\
\hline Age & .547 & .584 \\
\hline Educational attainment & 2.434 & .104 \\
\hline Length of service in LSPU & .694 & .507 \\
\hline Status of appointment & 3.597 & $.039^{* * *}$ \\
\hline
\end{tabular}

***.Correlation is significant at the $\leq 0.05$ level

As shown in the above table, there are significant relationships between the civil status and status of appointment-profile and teaching performance. This signifies that the aforesaid profile-variables were important in rating the teaching effectiveness. This finding indicates that the teacher's way of teaching and efficacy are affected by the faculty characteristics. This information may be useful in the faculty training program and serves as a guide in higher education classrooms particularly in criminology education.

On one hand, profile characteristics such as gender, age, religion, educational attainment and length of service are found to have not significantly related to the teaching effectiveness. This means that the mentioned profile-variables were not significant factors on teaching effectiveness. This result is however surprising and unexpected as one would think that the older faculty with higher educational qualification and more teaching experience could perform better in teaching compared to those younger faculty with lower educational qualification and less teaching experience. This could be attributed to the fact that even younger faculty with lower educational qualification and less teaching experience could have gone for a series of training and faculty development and as such acquired professional skill in teaching.

Table 6. Test of the Significant Relationship between the Teaching Effectiveness and Morale of Criminology Faculty of LSPU

\begin{tabular}{|c|c|c|}
\hline Variables & r-value & p-value \\
\hline $\begin{array}{c}\text { Teaching Effectiveness and } \\
\text { Morale }\end{array}$ & 0.063 & 0.724 \\
\hline
\end{tabular}

***.Correlation is significant at the $\leq 0.05$ level

Table 6 indicates that there was no relationship between teaching performance and morale of the respondents $(\mathrm{r}=0.063, \mathrm{p}<0.724)$. The finding implies that regardless of whether the faculty maintains high or low morale, they manage to perform at their best on their work. This may reflect that the respondents are more patient and content with what they have. They just have to make the most of what they have. Also, this may be attributed to their awareness of their responsibilities and accountabilities since they recognize what is expected of them as educators. This shows that as the teaching performance goes higher, they do not maintain low level of morale less often; and as the teaching performance goes lower, they do not maintain low level of morale more often. It indicates that a faculty who maintains high level of morale more often is not an indicator that he performs better.

The result was similar to the findings of Dubey [26] in which no significant correlations existed between the educators' work motivation and teaching performance. Furthermore, Eggers [27] research results ascertained that there was no significant relationship between teacher's morale levels and the teacher's effectiveness scores.

However, Sehang et al. [28] study indicated a positive and significant relationship between morale and teacher performance. Hence, teacher performance can be enhanced 
by improving morale. Also, the study of Solomon, Limjuco \& Babiera [29] did not support the mentioned findings since it was revealed that motivational potentials were significant predictors of performance.

Additionally, Abdullah, Yiing \& Ling [30] study did not corroborate the present finding since it indicated that the dimensions of teacher's morale such as relationship with the principals, relationship among teachers, curriculum issue, teacher's status in the community, facilities and school and school services, and community pressure emerged as significant predictor of school effectiveness.

\section{Conclusions}

Based on the results, it was concluded that the Criminology faculty of LSPU perform beyond the acceptable level of effectiveness and maintain a high level of morale. However, the Administrator may actively engage the faculty in the decision-making process. This will help to open the lines of communication between the Administrator and the faculty; thus, this can help increase the morale. Similarly, there is a necessity for the enhancement of respondents' morale on public relations. With this, administrators may consider the significance of developing a strong community relationship between the faculty.

Additionally, since the results indicated a significant relationship between civil status and status of appointment-profile and teaching effectiveness of criminology faculty of LSPU, this signifies that the aforesaid profile-variables are important in rating the teaching effectiveness of the faculty. This implies that the teacher's way of teaching and efficacy are affected by the faculty characteristics. This information may be useful in the faculty training program and serve as a guide in higher education classrooms, particularly in criminology education.

Although no significant influence was found between teaching effectiveness and morale, it still provides an important perspective as to what is necessary to further develop and foster a working environment that will aid them to be the best possible resource of the University.

Given the importance of faculty effectiveness and their morale, the University is expected to take the initiative to improve the same. In this way, the faculty's performance and their morale should be given a priority in the planning of any University policy focused on faculty development program. With it, faculty of Criminology will perform responsibilities with initiatives to continually improve the quality of education delivered to their clientele, particularly students, and contribute to the realization of the University's vision, mission and quality policy.

\section{Recommendations}

Based from the results and conclusions of the study, the researchers endorsed the following: given that the ratings of "Very Good" in teaching effectiveness were revealed, it is recommended that the Criminology faculty make it "Outstanding" rating in the future since there is still room for improvement; since the faculty morale in terms of public relations is above average only, it is suggested that the Dean, Associate Deans, and the faculty may recognize the importance of building a strong school community and relationship between sense of community and faculty morale; it is suggested that the results of the study be known to the administrators and supervisors (Dean and Associate Deans) to see that their faculty are satisfied employees who have a genuine interest in their own success and the University's success, in addition to the faculty to further maintain the strengths and overcome the weaknesses in their teaching effectiveness; the findings and conclusions of this endeavor may be used by the University as basis for policy formulations on faculty development programs; and it is recommended that a follow-up study be conducted in order to ascertain the reason why the teaching effectiveness has no influence on morale. Furthermore, future researchers are encouraged to conduct similar studies with wider scope and explore other variables not included in this endeavor in order to supplement the findings of this present undertaking.

\section{REFERENCES}

[1] Al-Zo'ibi, Z. H. \& Mahasneh, A. M. (2019). The level of motivation of the faculty members to teaching at the Hashemite University. International Journal of Environmental \& Science Education, 14(2) 71-83.

[2] Itniong, S.F.L. (1998). Teachers' characteristics and the academic achievements of the students in the public secondary school of the municipalities of Maigo and Bacolod, Lanao Del Norte. Unpublished thesis. Misamis University, Ozamis City.

[3] Portades, R. L. (2008). The level of teaching effectiveness of social sciences teachers of Fourth Congressional District of Quezon SY 2007-2008. (Master's Thesis). Manuel S. Enverga University Foundation-Lucena. Lucena City, Quezon.

[4] Rauf, M., Akhtar, M. S., Iqbal, Z., \& Malik, M. A. (2013). Relationship between morale and job satisfaction of subject specialists teaching in higher secondary schools of Khyber Pakhtunkhwa, Pakistan. The Dialogue, 8(1), 69-83.

[5] Shalem, Y., \& Hoadley, U. (2009). The dual economy of schooling and teacher morale in South Africa. International Studies in Sociology of Education, 19 (2), 119-134.

[6] Rasheed, M. I., Aslam, H. D. \& Sarwar, S. (2010). Motivational issues for teachers in higher education: A critical case of IUB. Journal of Management Research, 2(2), $1-23$.

[7] Bayona, M. M. (2018). The leadership styles of the school 
administrators and their effects on the level of faculty morale in selected elementary public schools in the division of Cavite, Unpublished Master's Thesis. De La Salle University-Dasmariñas, Dasmariñas, Cavite.

[8] Bivona, K. N. (2002). Teacher morale: the impact of teaching experience, workplace conditions, and workload. Retrieved from https://eric.ed.gov/?id=ED467760

[9] Houchard, M. A. (2005). Principal leadership, teacher morale, and student achievement in seven schools in Mitchell County. North Carolina.

[10] Whitaker, T., Whitaker, B., \& Lumpa, D. (2000). Motivating \& inspiring teachers: The educational leader's guide for building staff morale. Larchmont, NY: Eye on Education. Research, 3(2), 159-177.

[11] Dubey, A. (2018). What shape up teachers' morale? a study among higher secondary school teachers in Balodabazar District of Chhattisgarh. SUMEDHA Journal of Management, 7(1), 23-33. Retrieved fromhttp://pdqsoftech. com/MBA_DEMO/ADMIN/journal_attachment/15481425 95 1066680306.pdf

[12] Goldstein, A. (2015). Teachers' perceptions of the influence of teacher collaboration on teacher morale. Dissertation. Walden University. Retrieved from https://scholarworks.wa ldenu.edu/cgi/viewcontent.cgi? article $=1222 \&$ context $=$ disse rtations

[13] Hasan, S. A. (2011). Can Co-Workers Motivational Efforts Pave the Way for Morale and Job Commitment for Employees? European Journal of Economics, Finance and Administrative Sciences, 43.

[14] Brown, J. S. \& Richard A. (2008). Minds on Fire: Open Education, the Long Tail, and Learning. Educational Review. Retrieved from http://net.educause.edu/ir/library/pdf/ERM0 811.pdf

[15] Harthy, S.S.H.L., Jamaluddin, S. \& Abedalaziz, N. A. (2013). Teachers' attitudes and performance: an analysis of effects due to teaching experience. International Interdisciplinary Journal of Education, 2 (9).

[16] Usop, A.M., Askandar, K., Langguyuan-Kadtong, M. \& Usop, D.A.S.O. (2013). Work performance and job satisfaction among teachers. International Journal of Humanities and Social Science, 3(5), 245-252.

[17] Chella Pandian, K. (2009). A study on employees' morale in textile mills in Dindigul District. (Doctorate thesis). Madurai Kamaraj University, India. Retrieved from http://hdl.handle.net/10603/139505

[18] Nicodemus, J. C. (2011). Induction program, performance, and morale of teachers in selected schools in DepEd, Cavite City. Unpublished master's thesis. Technological University of the Philippines, Manila, Philippines.

[19] Tanang, H. \& Abu, B. (2014). Teacher professionalism and professional development practices in South Sulawesi, Indonesia. Journal of Curriculum and Teaching, 3(2), 25-42.
[20] Penfold, K. L. (2011). Increasing staff morale in today's school climate with increased teacher responsibilities, high-stakes testing, and decreased school funding. (Master's thesis). Northern Michigan University, Marquette, Michigan. Retrieved from https://www.nmu.edu/sites/DrupalEducatio n/files/UserFiles/Files/Pre-Drupal/SiteSections/Students/Gr adPapers/Projects/Penfold_Kristina_MP.pdf

[21] Hidalgo, J.G., Lamberte, L.A.H. \& Manalo, F.C. (2016) Performance of criminology instructors in Batangas State University-JPLPC Malvar Campus. Unpublished undergraduate thesis. Batangas State University-JPLPC Malvar Campus, Malvar, Batangas.

[22] Verceles, P.B. \& Rivera, N.C. (2006). Faculty teaching performance profile of the College of Education. Research Digest, 8(2), 54-60.

[23] Agsalud, P.L. (2017). Teaching effectiveness of the teacher education faculty members in Pangasinan State University Asingan Campus, Philippines. Asia Pacific Journal of Multidisciplinary Research, 5(1), 16-22.

[24] Sali-ot, M.A. (2011). Competencies of instructors: Its correlation to the factors affecting the academic performance of students. JPAIR Multidisciplinary Journal, 6, 31-51.

[25] Umali, R. M. (2010). Teachers' performance and the related factors of different colleges at Laguna State Polytechnic University San Pablo City Campus Academic Year, 2010-2011. (Research Paper). Laguna State Polytechnic University-San Pablo City Campus. San Pablo City, Laguna.

[26] Dubey, D. (2010). Work motivation, assertiveness, teaching competence, and teaching performance among maritime educators. Research Journal College of Engineering JBLFMU-Molo, 3(1). Retrieved from http://ejournals.ph/for $\mathrm{m} /$ cite.php?id $=10081$

[27] Eggers, B. D. (2012). Teacher morale in Rural Northeast Tennessee. Dissertation. Electronic Theses and Dissertations. Paper 1482. East Tennessee State University, Johnson City, Tennessee. Retrieved from https://dc.etsu.edu/etd

[28] Sehang, F., Rawis, J.A.M., Simandjuntak, S. \& Daniel Kambey, D. (2017). Relationship between morale and the teacher performance at Adventist Junior High School of North Sulawesi Province. IOSR Journal of Research \& Method in Education (IOSR-JRME), 7 (4), 23-28. DOI: $10.9790 / 7388-0704042328$

[29] Solomon, J.Y., Limjuco, R.P. \& Babiera, R.M. (2017). Rethinking the changing academic atmosphere: work engagement, motivational potential and performance of employees of the University of the Immaculate Concepcion. International Journal of Education Research for Higher Learning, 23(2). Retrieved from http://ejournals.ph/form/cit e.php?id=13375

[30] Abdullah, A.G.K., Moh Heng Yiing, M.H. \& Ling, Y.L. (2016). Teachers' morale and school effectiveness in secondary schools of Sibu, Sarawak. International Journal of Education, Culture and Society, 1(2), 52-57. doi: $10.11648 /$ j.ijecs.20160102.14 